\title{
Bringing the EU up to speed in the protection of living standards through fundamental social rights: Drawing positive lessons from the experience of the Council of Europe
}

Maastricht Journal of European and Comparative Law 202I, Vol. 28(5) 60I-625 (C) The Author(s) 2021 Article reuse guidelines: sagepub.com/journals-permissions DOI: $10.1177 / 1023263 \times 211021765$ maastrichtjournal.sagepub.com

\section{Ane Aranguiz*(1)}

\begin{abstract}
Ever since the adoption of the European Pillar of Social Rights, the EU seems committed to explore and expand its social dimension to deliver a decent standard of living to the European society. This new endeavour gives rise to a number of questions, not least regarding how the notion of a standard of living that is compatible with a life in dignity ought to be interpreted and what the obligations of Member States are in this quest. The aim of this contribution is precisely to shed some light on these questions. To this end, the article looks into how different (quasi)judicial bodies have interpreted fundamental rights that entitle individuals to minimum subsistence resources that are deemed to achieve a standard of living that is compatible with the right to human dignity. In particular, it analyses how the ECJ, the ECtHR and the ECSR have interpreted (minimum) living standards through different fundamental rights. It then suggests a number of 'learning points' for the ECJ to draw from the experience of the other two bodies and emphasizes the need for building solid bridges between the three.
\end{abstract}

\section{Keywords}

Living standards, human dignity, social protection, social rights, European Court of Justice, European Court of Human Rights, European Committee of Social Rights

\footnotetext{
* Tilburg University, Tilburg, The Netherlands; University of Antwerp, Antwerp, Belgium

Corresponding author:

Tilburg University, M209, Professor Cobbenhagenlaan 22I, 5037 DE Tilburg, The Netherlands.

E-mail: a.aranguiz@tilburguniversity.edu
} 


\section{Introduction}

For the last couple of years, the EU has regained consciousness of the importance of boosting its social dimension beyond its macroeconomic and fiscal interest. Partly as a way to make amends for the poor choices taken in the context of the 2007 financial crisis, in 2017 the Commission launched the European Pillar of Social Rights (EPSR), which was later interinstitutionally proclaimed by the Council and the Parliament. Ever since, the EU has taken numerous steps towards an active stance in ensuring a decent standard of living, the last of them being the Action Plan on the implementation of the EPSR. ${ }^{1}$ Recent discussions on protecting social rights in Europe have focused, inter alia, on ensuring fair minimum wages, ${ }^{2}$ access to social protection ${ }^{3}$ and more recently, minimum income protection, ${ }^{4}$ all of which relate one way or another to adequate living standards in the form of income or income replacement.

Far from discontinuing these efforts after the latest hit to the European society, the EU appears to have reinforced its social standpoint in the context of the Covid-19 crisis. At the time where the EU seems more committed than ever to deliver a decent standard of living for its population, the question of how a 'decent' or 'adequate' standard of living should be interpreted becomes more relevant than ever.

In order to shed some light onto this interpretation, this article studies how different European (quasi)judicial bodies have interpreted the idea of living standards through the lens of fundamental rights. Not only does this article aim at bringing some clarity to the otherwise abstract idea of living standards, but it hints at a number of discrepancies between the different bodies. Such discrepancies, it is argued, could hide a problematic interplay between the different bodies.

This contribution compares how different authoritative bodies have interpreted the living standards that are sufficient to achieve a certain standard of living compatible with the right to human dignity. The purpose of this analysis is twofold. First, it aims at substantiating a number of social rights in the Charter of Fundamental Rights (CFR) that have so far been used rather marginally. Secondly, it has the ambition to flesh out, or at least serve as an interpretative aid for, the provisions regarding 'adequacy' on the new (and future) social initiatives of the EU. To this end, this article looks into how the European Court of Justice (ECJ), the European Court of Human Rights (ECtHR) and the European Committee of Social Rights (ECSR) have interpreted living standards through fundamental rights.

In what follows, I first discuss the link between the right to human dignity, social rights and the protection of living standards. The following three sections analyse the case-law of the ECJ, ECtHR, and ECSR respectively on how living standards have so far been interpreted. In section 6 , I argue that the ECJ has some catching up to do and that this is possible by creating better synergies. This section puts forward a number of reasons for better synergies and suggests a number of unambiguous learning points for the EU judiciary and legislator. The last section concludes.

1. Commission, European Pillar of Social Rights Action Plan, 2021.

2. Proposal for a Directive of the European Parliament and the Council on adequate minimum wages in the European Union, 28 October 2020, COM(2020) 682 final.

3. Council Recommendation of 8 November 2019 on access to social protection for workers and the self-employed, [2019] OJ C 387.

4. Council Conclusions on Strengthening Minimum Income Protection to Combat Poverty and Social Exclusion in the Covid-19 Pandemic and Beyond, 25 September 2020. 


\section{Human dignity and living standards}

Traditionally, human dignity has been associated with civil and political rights, but it also has important implications for socioeconomic rights. The premise behind this is simple: in order to live a life in dignity a certain standard of living is necessary, which should translate into a number of safeguards - whether procedural or substantial - for individuals to not fall beneath an acceptable threshold. This threshold often relates to a situation of (extreme) poverty. This claim is frequently interpreted as a right that entitles individuals to a financial or other sort of entitlement, such as social protection, access to services or a minimum remuneration for work.

The relationship between human dignity and socioeconomic rights is evident from a number of different international human rights instruments. Article 22 UDHR, most clearly, enshrines the need of fulfilling the right to social security as a means of ensuring human dignity. Likewise, Article 23 UDHR preserves the right to just and favourable remuneration for work that is sufficient to ensure the human dignity of the worker and her family that shall be combined with means of social protection. In a similar fashion, the EPSR also links human dignity to a number of independent rights, such as the right to fair wages (principle 6); minimum income (principle 14), old-age income and pensions (principle 15), and income support for the inclusion of people with disabilities (principle 17). The recent Action Plan includes minimum income, combating poverty and accessible housing as necessary for a life in dignity. ${ }^{5}$ For those falling under an unacceptable threshold, because of its high level of abstraction - necessary to serve as the basis for all human rights - human dignity is more likely to be invoked in combination with these other rights, making a clear correlation between the right to human dignity and access to welfare.

This connection is important at the EU level for at least two reasons. First, as a more abstract and all-encompassing right, human dignity may serve as a way to discover new fundamental rights or broadening the interpretation of existing ones. ${ }^{6}$ This could be the case of a court recognizing the individual right to minimum income or minimum wages as opposed to the more general rights to social protection or fair working conditions. In this vein, the recent EPSR identifies 20 individual rights that could serve as an aid to interpretation when fleshing out, in the case of the EU, Articles 31 and 34 CFR.

Second, human dignity represents the essence of every other human right in the CFR and this substance cannot be restricted. It follows that human dignity represents the unlimitable core of every other provision. As an absolute right, this inviolable core can be seen as what some have called an absolute limit on limitations. ${ }^{7}$ Now, how this core or essence has been interpreted varies among different (quasi)judicial bodies. This is precisely one of the key questions of the following sections, which look into how the right to human dignity and other specific provisions have interacted when delimiting a certain standard of living.

5. Commission, European Pillar of Social Rights Action Plan, 2021, p. 27.

6. C. Dupré, 'Article 1 - Human Dignity', in S. Peers et al. (eds), The EU Charter of Fundamental Rights: A Commentary (Hart Publishing, 2019), p. 7.

7. Lenaerts argues that a measure that breaches this 'essence' is automatically disproportionate, hence, particular focus needs to be drawn to how the principle of proportionality is applied when limiting social rights. K. Lenaerts, 'Limits on Limitations: The Essence of Fundamental Rights in the EU', 20 German Law Review (2019) 779 at 786. 


\section{The ECJ}

\section{A. Human dignity and minimum subsistence}

At least rhetorically, human dignity holds a central position in the EU. Besides a self-standing right (Article 1 CFR), human dignity is also among the foundational values of the EU (Article 2 TEU) and together with Article 21 TEU on external action, it symbolizes a benchmark commitment for the respect of human dignity within and outside the EU. This is also reflected in secondary legislation, regarding minimum subsistence, most clearly seen in the case of the standard of living for asylum seekers, which includes medical care, access to education and the labour market and residence. $^{8}$

Before any of these provisions were in place, however, the EU was already familiar with the protection of human dignity through the general principles of EU law, which have long been used to protect vulnerable people, such as migrants or minors, and to ensure that their needs were somewhat covered, which reflects on the versatile nature of human dignity. ${ }^{9}$ This resourcefulness could very well be applied to those in a situation of poverty and social exclusion to protect their right to a minimum subsistence income.

The case-law of the ECJ on dignity in the form of a certain degree of living standards is scarce, particularly as regards the application of the CFR. Most cases before the ECJ involved situations of international protection, when a claimant had not received adequate minimum reception conditions. This is simultaneously linked to accessing some minimum resources. Saciri and Others concerned a family seeking asylum whose reception application and application for financial aid had been declined even when the family was unable to pay for rent. In this case, the ECJ explicitly recognized Member States' obligation to provide a dignified standard of living for third country nationals. According to the ECJ, this standard shall be adequate for the health of the applicants and capable of ensuring subsistence. The Court held that this obligation emanates directly from the right to human dignity as enshrined in Article 1 CFR. ${ }^{10}$

Abdida, differently, concerned an illegally staying migrant who had received a return decision but was severely ill and her removal could entail a 'grave and irreversible deterioration of health'. The ECJ held that because the applicant could not yet be removed, the Member State was required to provide basic needs for her. The Court - and even more clearly Advocate General Bot associated this obligation to Article 1 CFR. ${ }^{11}$ Similarly, the ECJ recently linked the right to human dignity to extreme material poverty. ${ }^{12}$ Jawo and Ibrahim had filed their application for international protection in one Member State and then moved to another. The ECJ acknowledged that usually a transfer to the country of application is possible, unless such transfer would expose the applicant to a situation of extreme material poverty. The Court argued that exposing the applicants to a transfer would be in breach of the prohibition of inhuman and degrading treatment and the right to human dignity. The Court, however, was very clear in emphasizing that mere inadequacies in the social protection system of a Member State are not sufficient by itself to conclude that there

8. Council Directive 2003/9/EC of 27 January 2003 laying down minimum standards for the reception of asylum seekers, [2003] OJ L 31.

9. C. Dupré, in S. Peers et al. (eds), The EU Charter of Fundamental Rights: A Commentary, p. 4-5.

10. Case C-79/13 Saciri and Others, EU:C:2014:103, para. 35.

11. Case C-562/13 Abdida, EU:C:2014:2453, para. 42 and Opinion of Advocate General Bot for this case, para. 106.

12. Joined Cases C-297/17, C-318/17, C-319/17 and C-438/17 Ibrahim, EU:C:2019:219, para. 90; Case C-163/17 Jawo, EU:C:2019:218. 
is a violation. In this regard, the Court stressed that a breach of the right to human dignity would only exist where:

the indifference of the authorities of a Member State would result in a person wholly dependent on State support finding himself, irrespective of his wishes and his personal choices, in a situation of extreme material poverty that does not allow him to meet his most basic needs, such as, inter alia, food, personal hygiene and a place to live, and that undermines his physical or mental health or puts him in a state of degradation incompatible with human dignity ${ }^{13}$

Later in Haqbin the Court applied a similar reasoning, this time with regard to an applicant who had been sanctioned with a reduction of his material reception conditions including the withdrawal or reduction of the daily expenses allowance. Again, the Court linked the situation of extreme poverty of the applicant to the right to human dignity under Article 1 CFR. In this case, the Court stressed that the competent authorities must comply with the principle of proportionality when imposing sanctions to ensure that such restrictions do not undermine the dignity of the applicant. ${ }^{14}$

In the above cases, the ECJ associated a certain standard of living to the right to human dignity, suggesting that every human being, regardless of their citizenship or economic status, should have access to such minimum subsistence level in order to see her right to human dignity fulfilled. However, there are two particularities to be noted from this case-law. First, all these cases concerned applicants in (or at risk of) extreme poverty and were completely reliant on the Member State for their survival. As such, to the extent that certain minimum resources are necessary for the survival of dependent individuals, the ECJ has held that a mandatory protection for a 'dignified' standard of living exists, which Member States ought to provide for. In this vein, there seems to be a differentiation between 'dignified' and 'decent' standards of living, where the protection of the latter, can be limited under certain circumstances. One could say that the absolute 'essence' materializes when two requirements collide: extreme circumstances and dependency. Under these circumstances, the Court has highlighted the case-by-case assessment to evaluate whether the measures imposed by the Member States breach the right to human dignity. In these cases, the risk of vulnerability of the applicant, particularly regarding the exposure to extreme poverty ought to be considered. ${ }^{15}$ Under extreme circumstances as the ones in these cases, the causal link between resources and human dignity appears to be more self-evident and, as a result, more justiciable.

A second marked characteristic of these cases is that they all concern international protection which, besides being a particularly strong international commitment, is also expressly covered in secondary legislation. These Directives, moreover, make a very clear connection between minimum resources and human dignity. Implementing acts like these can be essential in the justiciability of a right, as the judiciary is forced to read the act in light of fundamental rights. ${ }^{16}$ This raises the question of whether a similar outcome would have been reached where there is no implementing act.

13. These cases explicitly follow the ECtHR. Joined Cases C-297/17, C-318/17, C-319/17 and C-438/17 Ibrahim, para. 90; Case C-163/17 Jawo, para. 92. M. den Heijer, 'Transferring Refugee to Homelessness in Another Member State', 57 Common Market Law Review (2020) p. 539.

14. Case C-233/18 Haqbin, EU:C:2019:956, para. 46.

15. Ibid., para. 451 .

16. I.e. Recitals 18 and 35 of the preamble Directive 2013/33/EU, of the European Parliament and of the Council of 26 June 2013 laying down standards for the reception of applicants for international protection, [2013] OJ L 180. 
As a result, while there is little doubt that a clear relationship exists between human dignity and access to resources, only in extreme cases does the right to human dignity appear sufficient to substantiate these claims. The level of these resources is contested, but they should at least cover access to housing, food, clothing, health care, education for minors and, under certain conditions, access to employment. This, however, is dictated by the implementing acts, so it is not clear whether the same needs would be granted without an implementing act.

\section{B. The right to social protection}

The CFR also recognizes the right to fair working conditions and the right to social security and social protection under Articles 31 and 34 CFR respectively both part of the 'solidarity' title of the CFR.

Regarding the right to social security and social protection, Article 34 CFR enshrines, in each of its three paragraphs respectively, the right to social security; the right to social security coordination for those exercising free movement; and the right to social and housing assistance. According to the explanations of the CFR, the right to social security is based on Article 12 ESC (see below), Articles 153 and 156 TFEU regarding the social competences of the Union and the Community Charter of Fundamental Social Rights of Workers. It covers maternity, illness, industrial accidents, dependency or old age and unemployment. As for the second indent of the provision, it refers to freedom of movement and specific rights enshrined in a variety of secondary instruments. ${ }^{17}$ The third paragraph, on social and housing assistance, draws instead on Article 13 ESC and Articles 30 and 31 of the Revised ESC, discussed below, as well as on point 10 of the Community Charter. The fact that this provision directly addresses the issue of combating poverty and social exclusion seems to emphasize the commitment of the EU to social objectives as stated in Article 3(3) TEU, and Articles 9 and 153 TFEU (explicitly envisaged), by means of ensuring social and housing assistance in the Member States. Because mobility related rights are neutral, meaning that they do not grant a level but rather the access to welfare in another country (for example by means of equal treatment), this section will focus on the first and third paragraph instead.

Beyond the explanations of the Charter, however, it is not very clear what Article 34 CFR really entails or how it ought to be interpreted. The limited case-law of the ECJ has not helped in shedding much light onto the issue. This is probably a consequence of the provision being considered more of a principle than a right, and therefore having limited justiciability. In this vein, literature seems to agree that paragraphs 1 (explicitly called principle in the explanations) and 3 are formulated in the form of principles, and that the second paragraph, differently, constitutes a right. ${ }^{18}$ A strict interpretation of Article 52 CFR suggests that principles can only be used as a source of interpretation when they are implemented by an act. ${ }^{19}$ This would point to paragraphs 1

17. I.e. Regulation 883/2004 of the European Parliament and of the Council of 29 April 2004 on the coordination of social security systems, [2004] OJ L 166.

18. A. Kornezov, 'Social Rights, the Charter, and the ECHR: Caveats, Austerity, and Other Disasters', in F. Vandenbroucke, C. Barnard and G. De Baere (eds.), A European Social Union After the Crisis (Cambridge University Press, 2017), p. 423; R. White, 'Art 34 - Social Security and Social Assistance', in S. Peers et al. (eds), The EU Charter of Fundamental Rights: A Commentary (Hart Publishing, 2019), p. 936; E. De Becker, 'The (Possible) Role of the Right to Social Security in the EU Economic Monitoring Process', 17 German Law Journal (2016), p. 277.

19. Case C-356/12 Glatzel, EU:C:2014:350, para. 74. 
and 3 being merely a judicial safeguard for the protection of social security and social assistance rights, and therefore having a limited applicability. ${ }^{20}$

Not that the ECJ has not been confronted with cases regarding Article 34 CFR, but the Court decided that there was no need to examine the referring question in light of Article 34 CFR because the CFR was either not applicable or the question did not fall within the scope of EU law (Article $51 \mathrm{CFR}){ }^{21}$ This is the case for all the cases before the ECJ regarding the right to social security (paragraph 1). In Melchior, and soon after in Wojciechowski, AG Mengozzi clarified that Article 34(1) CFR constituted a principle and not a right and stressed that it only has a programmatic character for public authorities, as opposed to 'rights' which are prescriptive. In this regard he argued that in the absence of a legislative implementation, Article 34(1) CFR does not create rights to positive action and may only be invoked as 'interpretative reference or as parameters for ruling on the legality' of the implementing act. ${ }^{22}$ The literature too supports a strict reading of the CFR explanation and seems to support such a narrow understanding of Article 34(1) CFR. ${ }^{23}$ The fact that Article 34(1) CFR is catalogued as a principle considerably limits its enforceability. Accordingly, Article 34(1) CFR does not represent a claim-right, which suggests a rather scant judicial safeguard of the right to social security under EU law. The lack of enforceability of Article 34(1) CFR was further undermined by the General Court that held that the financial stability of the eurozone constitutes an objective of general interest that may justify restrictions to the right to social security and reductions of the public spending. This is what the General Court ruled in Sotiropoulou where it decided that insofar as they are necessary to meet fiscal compliance in the Eurozone and to pursue the financial stability of the same, pensions might be reduced. ${ }^{24}$

Article 34(3) CFR, in turn, has only been successfully invoked once before the ECJ. This was in Kamberaj, a case concerning the entitlements to housing assistance of a legally residing long-term third-country national. The dispute concerned an Albanian national who had been residing longterm in Italy and had been refused housing benefits on the basis that the funds to provide housing benefits for third-country nationals were exhausted. ${ }^{25}$ While under this Directive Member States are allowed to limit equal treatment with regard to social assistance and social protection, 'core benefits' have to be protected at all times. The Court was then left to decide whether the benefits at stake were to be considered 'core'. After confirming that Member States must comply with the CFR when defining national social security and social assistance measures, ${ }^{26}$ the Court held that 'core benefits' shall cover at least minimum income support, assistance in case of illness, pregnancy, parental assistance and long-term care. These 'core benefits' then go beyond social assistance to cover social security too. Moreover, in spite of 'housing' not being listed in the Directive, the ECJ considered this not to be an exhaustive list, and interpreted 'housing' as covering the basic

20. E. De Becker, 17 German Law Journal (2016), p. 277.

21. Case T-462/17 TO v. EEA, EU:T:2019:397; Case C-647/13 Melchior, EU:C:2015:54; Case C-408/14 Wojciechowski, EU:C:2015:591, para. 64; Case C-395/15 Daouidi, EU:C:2016:917; Case C-89/16 Szoja, EU:C:2017:538; Case C-447/ 18 Generálny riaditel Sociálnej poistovne Bratislava, EU:C:2019:1098; Case C-496/14 Văraru, EU:C:2015:312.

22. Case C-647/13 Melchior, para. 60.

23. A. Kornezov, in F. Vandenbroucke, C. Barnard and G. De Baere (eds.), A European Social Union After the Crisis, p. 423; and R. White, in S. Peers et al. (eds), The EU Charter of Fundamental Rights: A Commentary, p. 936.

24. Case T-531/14 Sotiropoulou and Others v. Council, EU:T:2017:297, para. 88.

25. Council Directive 2003/109/EC of 25 November 2003 concerning the status of third-country nationals who are longterm residents, [2004] OJ L 016.

26. Case C-571/10 Kamberaj, EU:C:2012:233, para. 90. 
needs of the claimant. Furthermore, the Court established that the EU recognizes the right to social and housing assistance to ensure a 'decent' existence for those lacking sufficient resources and gave a strong steer to the referring court by stating that:

in so far as the benefit in question [.] fulfils the purpose set out in that article of the Charter, it cannot be considered, under European Union law, as not being part of core benefits ${ }^{27}$

It follows from this judgment that those benefits that have the objective of combating poverty and social exclusion for those lacking sufficient resources are to be considered 'core benefits' Core benefits, in turn, are deemed to respond to basic needs such as food, accommodation and health. This was also the reasoning of Advocate General Bot. ${ }^{28}$

Kamberaj proved that even though Article 34 CFR has a soft wording resembling more a principle than a right, it provides a compelling guide of interpretation for EU legislation. ${ }^{29}$

Only in one other case did the ECJ receive a question regarding Article 34(3) CFR, which concerned a Spanish national who had lost his house for to not complying with the payments of the mortgage. Although in this case the ECJ did not find it necessary to rule on its interpretation, it did clarify that the provision does not enshrine the right to housing, but rather the right to housing assistance. $^{30}$

The interpretation in Kamberaj was possible because the implementing act, in casu Directive 2003/109, made specific reference to the CFR. However, the case did not clarify whether Article 34(3) CFR represents a right or a principle. In any case, the Court interpreted the Directive in light of Article 34(3) CFR even though the Directive vaguely referred to the CFR, where in Glatzel, by contrast, the Court required the objective of the legislative act to implement the principle of the CFR. ${ }^{31}$ While there was a clear difference in the approaches taken by the ECJ when interpreting 34(3) CFR and Article 26 CFR (in Glatzel), this alone cannot be used to conclude that Article 34(3) CFR enshrines a right and not a principle. As such, whether this provision could be enforceable where there is no implementing act remains to be seen in future case-law. For now, it is important to note that Article 34(3) CFR might be invoked in EU instruments that regulate to some extent welfare rights.

Whereas it remains unclear what 'implementing act' truly envisages, cataloguing a provision as a principle certainly has a limiting effect for Article 34(1) CFR. With the objective of promoting the effectiveness of principles under the CFR, many have called for a broader interpretation of these provisions that would ensure a higher degree of protection against measures that limit people's rights to social security (or other principles for that matter). This interpretation would allow principles to be invoked also when an act does not implement the principle but it clearly violates it. ${ }^{32}$ This would be in line with the social objectives of the EU to strive towards the realization of a social market economy (Article 3 TEU) and more specifically the horizontal mainstreaming of these provisions across all policy areas of the EU (Article 9 TFEU). However,

27. Ibid, para. 92 .

28. Opinion of Advocate General Bot in Case C-571/10 Kamberaj, EU:C:2011:827, para. 95.

29. R. White, in S. Peers et al. (eds), The EU Charter of Fundamental Rights: A Commentary, p. 940.

30. Case C-169/14 Sánchez Morcillo and Abril García, EU:C:2014:2099.

31. Case C-356/12 Glatzel, para. 75 .

32. D. Guðmundsdóttir, 'A Renewed Emphasis on the Charter's Distinction Between Rights and Principles: Is a Doctrine of Judicial Restraint More Appropriate?', 53 Common Market Law Review (2015), p. 685. 
in the absence of enlightening case-law of the ECJ in this regard, it seems difficult to argue that such a broad interpretation is feasible.

\section{A right to fair remuneration?}

Beyond resources outside work (whether permanently or temporarily for risks associated to work), given the increasing share of people experiencing in-work poverty, it is necessary to also take a look at the right to a fair remuneration. In this vein, the right to a fair remuneration is notoriously absent from the wording of Article 31(1) CFR on fair and just working conditions. Neither does the provision explicitly refer to it nor do the explanations, a choice that appears to have been deliberate since it was initially included in the list of social rights under the heading of 'working conditions' but it was not retained later on. ${ }^{33}$ However, an increasing number of scholars argue that Article 31(1) CFR, includes (or at least does not exclude) the right to a fair remuneration. ${ }^{34}$ According to the ECJ, working conditions also include 'pay, 35 although, when asked whether Article 31(1) CFR protected fair remuneration in the context of the austerity measures, the Court held that 'it had no jurisdiction' as the order for reference was not implementing EU law. ${ }^{36}$ This sits unwell alongside Bauer, where the Court admitted the horizontal direct application of Article $31 \mathrm{CFR} .{ }^{37}$ Lörcher argues that since Member States have ratified instruments that protect the right to a fair remuneration (see below), it follows from Article 53 CFR that Article 31(1) CFR should also include the right to a fair remuneration. ${ }^{38}$ This interpretation is backed by the fact that the EPSR, under its chapter on fair working conditions, recognizes the right to wages (principle 6) which enshrines the right to fair wages that provide a decent standard of living and refers to Article 31(1) CFR as part of the existing EU law in this field. This is further supported by the recent initiative of the Commission, which explicitly sees the proposal on minimum wages as implementing Article $31 \mathrm{CFR}^{39}$ The Community Charter too enshrined that 'all employment shall be fairly remunerated' (Point 5). There is, to date, no case-law on fair remuneration in the context of the ECJ.

\section{Assessment}

As regards human dignity and social protection in the CFR, beyond its implications for equal treatment and social security coordination, it has mostly served to cover the most basic needs, namely, food, accommodation and health. These basic needs have been associated with the obligation to provide international protection and claims have only been successful in extreme situations. In Kamberaj, differently, the Court read the right to housing assistance in the CFR as representing a 'core benefit' which, as a consequence, precludes the Member States from limiting

33. Draft Charter of Fundamental Rights of the European Union, [2000] Charte 4112/0/00 Rev 2 Body 4, p. 6.

34. J. Hunt, 'Fair and Just Working Conditions', in T. Hervey and J. Kenner (eds.), Economic and Social Rights under the EU Charter of Fundamental Rights: A Legal Perspective (Hart Publishing, 2003), p. 54; K. Lörcher, 'Article 31 - Fair and Just Working Conditions', in F. Dorssemont et al. (eds.), The Charter of Fundamental Rights of the European Union and the Employment Relation (Hart Publishing, 2019), p. 555.

35. Case C-395/08 Bruno and Others, EU:C:2010:329, para. 39; Case C-307/05 Del Cerro Alonso, EU:C:2007:3, para. 39.

36. Case C-264/12 Sindicato Nacional dos Profissionais de Seguros e Afins, EU:C:2014:2036, para. 19.

37. Case C-569/16 Bauer, EU:C:2018:871.

38. K. Lörcher, in F. Dorssemont et al. (eds.), The Charter of Fundamental Rights of the European Union and the Employment Relation, p. 555.

39. $\operatorname{COM}(2020) 682$ final, p. 19. 
the right to equal treatment for long-term third-country nationals. Some have argued that if Article 34 CFR is to be interpreted in light of Articles 12 and $13 \mathrm{ESC}$, it should act in the form of a safeguard against the deterioration of social security and social assistance systems. ${ }^{40}$ Following this interpretation, Article 34 CFR would entail a duty to protect existing social protection rights, therefore complying with Article 51(2) CFR. However, Sotiropoulou exemplifies not only that Member States might limit these rights, but also that they might do so by using the justification of fiscal consolidation in the Eurozone, without so much as a conclusive proportionality test to substantiate this justification. One may argue, alternatively, that fundamental rights in EU law provide a judicial safeguard not to limit social protection rights beyond these 'core' benefits, which are the very minimum necessary to comply with the absolute right to human dignity. This would represent the essence of Article 34 CFR, that if violated would breach the right to human dignity.

This argument, however, goes along with the important disclaimer regarding the issue of whether (core) benefits would have been protected under EU law had there not been an implementing legislative act. Even if 'implementing' only requires a mere reference to the CFR, it is doubtful that a similar outcome would have been reached without a Directive in place.

Regardless, there is no clear standard to evaluate the adequacy of these 'core' benefits to hold Member States accountable. In recent cases regarding old-aged pensions and the transfer of undertakings, however, the ECJ did use the proportionality test to establish that any possible reduction in pensions as a consequence of bankruptcy cannot result in a beneficiary being at risk of poverty and social exclusion. ${ }^{41}$ Whereas these judgments did not involve the right to human dignity or the CFR altogether, they are a reflection of the possibility of applying internationally recognized thresholds, such as the at-risk-of-poverty threshold (AROP, 60\% of the national median equivalized income).

In hopes of finding some substance to these fundamental rights and overcoming the obvious limitations at the EU level, the following two sections look into the two authoritative bodies of the Council of Europe $(\mathrm{CoE})$ respectively. Section 6 argues that looking into these bodies is also a normative requirement in the EU.

\section{The ECtHR}

As an instrument of civil and political rights, the ECHR does not incorporate social rights as such. Yet, it considers the respect for human dignity to be the very essence of the ECHR, ${ }^{42}$ and the ECtHR has, moreover, increasingly interpreted a number of provisions in the ECHR with a social dimension, thereby emphasizing the indivisibility of human rights. At times, some of these provisions in the ECHR have been interpreted as to provide or protect a certain standard of living. This section discusses a number of these.

40. E. De Becker, 17 German Law Journal (2016), p. 299; S. Peers and S. Prechal, 'Scope of Interpretation of Rights and Principles', in S. Peers et al. (eds), The EU Charter of Fundamental Rights: A Commentary, p. 1455.

41. Case C-674/18 TMD Friction, EU:C:2020:682, para. 80 and 86; Case C-168/18 Pensions-Sicherungs-Verein, EU:C:2019:1128, para. 44.

42. ECtHR, Bouyid v. Belgium, Judgment of 28 September 2015, Application No. 23380/09. ECtHR, Lambert v. France, Judgment of 5 June 2015, Application No. 46043/14; Pretty v. the United Kingdom, Judgment of 29 April 2002 , Application No. 2346/02. 


\section{Inhuman treatment and access to resources}

Much like the case-law of the ECJ, the ECtHR too has found violations in situations of extreme poverty when evaluating cases of international protection. This has led the ECtHR to find breaches of Article 3 ECHR on the prohibition of inhumane and degrading treatment when a contracting party failed to provide essential support, particularly in cases regarding health, housing and social benefits, but only when there was a considerable degree of severity. ${ }^{43}$

This degree was visible in O'Rourke $v$. United Kingdom, when the ECtHR declared the case inadmissible on the grounds of Article 3 ECHR because 'mistreatment must attain a minimum level of severity'. The Court reached this conclusion because in this case, the claimant, had refused to attend a night shelter (as advised by the national authorities) and had previously refused temporary accommodation. ${ }^{44}$ Because the claimant had been offered opportunities for shelter, the threshold of severity was not reached. The ECtHR clarified this point in Budina $v$. Russia stating that there could be a violation of Article 3 ECHR where an applicant wholly dependent on State support found her/himself faced with official indifference when in a situation of serious deprivation or want incompatible with human dignity. ${ }^{45}$ In M.S.S. Belgium and Greece, otherwise, the Court found that the claimant, an asylum seeker who due to State inaction was living on the streets for several months lacking access to resources or sanitary facilities, had been victim to humiliating treatment because of the lack of respect to his right to human dignity. ${ }^{46}$ The conditions the claimant was exposed to combined with the prolonged uncertainty and the total lack of improvement prospect, attained the level of severity required by the ECtHR. In a more recent judgment, V.M and Others $v$. Belgium, the ECtHR emphasized the need to give sufficient consideration to the vulnerability of the applicants. In this case, the applicants for asylum were ordered to leave Belgium following a decision to return them to France. Consequently, the applicants were expelled from the reception centre which led them to spend four months in homelessness. Because of this, the Court considered that Belgium had failed to fulfil its obligation to not expose the applicants to extreme poverty conditions as they had no access to sanitary facilities, no means of meeting their basic needs and no prospect of improvement of their situation. $^{47}$

As regards this case-law, the ECJ and ECtHR seem to follow a rather similar approach where Member States maintain an obligation to provide for minimum subsistence resources in cases of extreme vulnerability and dependency on the State. The main difference in these cases lies in the consideration for the prospect of improvement, which, so far, the ECJ has not taken on board.

43. The ECtHR will not assess or review the level of financial benefits but may review a complaint about a wholly insufficient amount of social benefits under Article 3 ECHR. ECtHR, Larioshina v. Russia, Judgment of 22 March 2012, Application No 56869/00.

44. ECtHR, O'Rourke v. United Kingdom, Judgment of 26 June 2001, Application No. 39022/97.

45. ECtHR, Budina v. Russia, Decision of 18 June 2009, Application No. 45603/05; ECtHR, Paposhvili v. Belgium, Judgment of 13 December 2016, Application No. 41738/10; ECtHR, N. v. United Kingdom, Judgment of 27 May 2008 , Application No. 26565/05.

46. ECtHR, M.S.S. v. Belgium and Greece, Judgment of 21 January 2011, Application No. 30696/09, para. 263.

47. ECtHR, V.M. and Others v. Belgium, Judgment of 17 November 2016, Application No. 60125/11. In another case the ECtHR found no violation of Article 3 ECHR because there was prospect of improvement: ECtHR, N.T.P. and Others v. France, Judgment of 24 May 2018, Application No. 68862/13. 


\section{A. A right to social protection?}

The ECHR does not contain a specific right to social security or social protection. However, the interpretation of the ECtHR has increasingly followed a trend towards providing (at least procedural) safeguards to access welfare through a number of provisions. This is the case, inter alia, of Article 1 Protocol 1 on the right to property and Article 8 ECHR on the respect for private and family life. These have often been combined with Article 14 ECHR on the prohibition of discrimination that, while not an independent right in itself, has had an independent impact on those in vulnerable situations. In Gaygusuz, for instance, the applicant invoked Article 14 ECHR in a case concerning emergency assistance after he had been denied such a service on the basis that he did not have an Austrian nationality. ${ }^{48}$ The Court stressed that such different treatment would only be justified by very weighty reasons, and while the Austrian government claimed its special responsibility to protect their own nationals, the Court did not accept that argument. ${ }^{49}$

Article 1 Protocol 1 has successfully been invoked before the ECtHR in matters related to social protection. Traditionally, the ECtHR had only recognized the right to property in cases that have a direct link between the level of contributions paid and the benefits awarded. ${ }^{50}$ More recently, the Court deviated from this case-law to also cover non-contributory benefits under the right to property. ${ }^{51}$ In Stec v. United Kingdom, the ECtHR recognized that because of the wide range of social security entitlements that are financed in diverse ways, a different interpretation would have deprived individuals in certain welfare states from the same protection level. ${ }^{52}$ Regardless of how benefits are funded, the protection of property only applies to existing possessions and, as such, there is no obligation for States to grant social security benefits that are not in place. ${ }^{53}$ When they do exist, however, Article 1 of Protocol, read in conjunction with Article 14 ECHR, may preclude national authorities from refusing benefits on grounds of sex, marital status or nationality. ${ }^{54}$

What is interesting from this line of case-law is how the ECtHR has applied the principle of proportionality in cases where the contracting parties limit the right to property, which particularly emphasizes the burden imposed on individuals, which shall not be excessive. Remarkably, in

48. ECtHR, Gaygusuz v. Austria, Judgment of 16 September 1996, Application No. 17371/90.

49. A. Światkowski and M. Wujczyk, 'The European Social Charter as a Basis for Defining Social Rights for EU Citizens', in F. Pennings and M. Seeleib-Kaiser (eds.), EU Citizenship and Social Rights (Elgar, 2018) p. 23.

50. ECtHR, Müller v. Austria, Commission decision of 4 December 1984, Application No. 5849/72, p. 49; ECtHR, G. v. Austria, Commission decision of 14 May 1984, Application No. 10094/82, p. 86; ECtHR, F.P.J.M. Kleine Staarman v. the Netherlands, Commission decision of 16 May 1985, Application No. 10503/83, p. 166.

51. ECtHR, Bucheň v. the Czech Republic, Judgment of 26 November 2002, Application No. 36541/97, para. 46; ECtHR, Koua v. France, Judgment of 30 September 2003, Application No. 40892/98, para. 37.

52. ECtHR, Stec v. the United Kingdom, Judgment of 12 April 2006, Application No. 65731/01 and 65900/01, para. 51.

53. ECtHR, Sukhanov v. Ukraine, Judgment of 26 June 2012, Application No. 68385/10 and 71378/10, para. 36; ECtHR, Kolesnyk and Others v. Ukraine, Judgment of 3 June 2014, Application No(s). 57116/10, 78847/10 and 10642/11, para. 89.

54. ECtHR, Sali v. Sweden, Judgment of 10 October 2006, Application No. 67070/01; ECtHR, Goudswaard-Van Der Lans v. the Netherlands, Judgment of 22 September 2005, Application No. 75255/01. ECtHR, Willis v. the United Kingdom, Judgment of 11 June 2002, Application No. 36042/97; ECtHR, Wessels-Bergervoet $v$. the Netherlands, Judgment of 4 June 2002, Application No. 34462/97; ECtHR, Koua v. France, F. Tulkens, 'La Convention européenne des droits de l'homme et la crise économique. La question de la pauvreté', 1 Journal européen des droits de l'homme (2013), p. 13; L. Lavrysen, 'Strengthening the Protection of Human Rights of Persons Living in Poverty under the ECHR', 33 Netherlands Quarterly of Human Rights (2016), p. 300; R. White, in S. Peers et al. (eds), The EU Charter of Fundamental Rights: A Commentary, p. 931. 
N.K.M. v. Hungary, the Court explicitly referred to Article 34 CFR in a case concerning a Hungarian national who had been taxed excessively on her statutory entitlement corresponding to an unused leave of absence after being dismissed. The ECtHR used this to support its argument regarding the disproportionate burden placed on the individual as a consequence of such high taxation. ${ }^{55}$ This interpretation has consequently been reiterated in similar cases. ${ }^{56}$ More recent cases have gone a step beyond by establishing that when applying the principle of proportionality, whether the applicant received a subsistence minimum ought to be considered, even when the conditions for entitlement of such benefit have not been met. ${ }^{57}$ In other cases, the ECtHR has emphasized the need to protect particularly vulnerable groups, such as victims of gender violence, from public expenditure cuts even when a legitimate aim exists. ${ }^{58}$ This case-law exhibits a clear trend towards protecting claimants' minimum subsistence benefits through an increasingly social interpretation of the right to property under the ECtHR, which has drawn positive obligations in the form of a procedural safeguard to favour the poor. ${ }^{59}$

Article 8 ECHR on the right to private and family life has also been successfully invoked by those in a situation of financial distress. In R.M.S. v. Spain, the ECtHR clarified that in order to comply with the proportionality test, the welfare authorities have to guide individuals through the necessary steps and advise them on the possibilities with regard to the welfare system as to avoid taking too drastic measures. In this case, the applicant claimed a breach of the right to family life because the social authorities, taking note of the poor financial situation of Ms. R.M.S, had placed her daughter in a children's home. The Court agreed with the applicant and found that the Spanish authorities should have considered less drastic measures before placing the child in the children's house. ${ }^{60}$

This provision also covers the respect for home, which does not entail a positive obligation to provide a home, but instead protects existing homes. ${ }^{61}$ In this vein, Article 8 ECHR has been used in cases of eviction where vulnerable individuals or groups may suffer from eviction in a disproportionate way. ${ }^{62}$ In MacCan $v$. the UK, the Court stressed that '[ $t$ ] he loss of one's home is a most extreme form of interference with the right to respect for the home', ${ }^{63}$ which led the ECtHR to emphasized that to comply with the ECHR, any eviction measure had to be reviewed under the proportionality test. Unlike what the ECJ decided in Kamberaj, however, the ECtHR did not see a

55. ECtHR, N.K.M. v. Hungary, Judgment of 14 May 2013, Application No. 66529/11, para. 70.

56. ECtHR, Gáll v. Hungary, Judgment of 25 June 2013, Application No. 49570/11, para. 69; ECtHR, R.Sz v. Hungary, Judgment of 2 July 2013, Application No. 41838/11, para. 59.

57. ECtHR, Béláné Nagy v. Hungary, Judgment of 13 December 2016, Application No. 53080/13; Baczùr v. Hungary, Judgment of 7 March 2017, Application No. 8263/15; Čakarević v. Croatia, Judgment of 26 April 2018, Application No. 48921/13.

58. ECtHR, J.D. and A v. The United Kingdom, Judgment of 24 October 2019, Application No. 32949/17 and $34614 / 17$.

59. I. Leijten, 'The Right to Minimum Subsistence and Property Protection under the ECHR: Never the Twain Shall Meet?', 21 European Journal of Social Security (2019), p. 307: D. Kagiaros, 'Austerity Measures at the European Court of Human Rights: Can the Court Establish a Minimum of Welfare Provisions?', 25 European Public Law (2019), p. 535 .

60. ECtHR, R.M.S. v. Spain, Judgment of 18 June 2013, Application No. 28775/12, para. 84; ECtHR, Zhou v. Italy, Judgment of 21 January 2014, Application No. 33773/11; previously: ECtHR, Wallova and Walla v. the Czech Republic, Judgment of 26 October 2006, Application No. 23848/04.

61. ECtHR, Chapman v. the United Kingdom, Judgment of 18 January 2001, Application No. 27238/95, para. 99.

62. L. Lavrysen, 33 Netherlands Quarterly of Human Rights (2016), p. 300.

63. ECtHR, McCann v. the United Kingdom, Judgment of 27 May 1995, Application No. 18984/91, para. 50. 
violation of Article $8 \mathrm{ECHR}$ (or Article $14 \mathrm{ECHR}$ ) in Bah v. the UK when the UK refused to give priority to a Turkish national for the allocation of a grant social housing. Instead, it gave the UK a wide margin of appreciation because the benefit in question was predominantly socioeconomic in nature. ${ }^{64}$ This judgment did not prevent the Court from taking a different position in two subsequent cases, Yordanova and Winterstein, where the Court required contracting parties to establish sufficient procedural safeguards against eviction for individuals that would otherwise be left homeless. In addition, the Court held that under exceptional circumstances Article 8 ECHR may embody an obligation to secure shelter. ${ }^{65}$ According to Tulkens, these judgments inevitably point towards a right to housing under the ECHR. While not being a right that is enshrined in the ECHR, she argues, it most definitely represents an interest that has been part of the case-law of the ECtHR, in particular when exercising a balancing test when potentially restricting property rights. ${ }^{66}$ In this vein, just as for other provisions under the ECHR, Article 8 too provides a procedural obligation for Member States to conduct a proportionality test when the right respect the home is jeopardized. This makes an interesting parallel with the case-law of the ECJ, where the Court interpreted Article $34(3)$ as not covering the right to housing but just the right to a housing allowance. In view of the case-law of the ECtHR, the Luxembourg Court could have (or even should have) read this case in light of Article $7 \mathrm{CFR}$, which is the analogous to Article $8 \mathrm{ECHR}^{67}$

A last point regarding the ECHR protecting certain living standards is how the Court has balanced opposing fundamental rights, particularly when social rights have been restricted. In such cases, the ECtHR has followed a threefold step. First, any restriction to fundamental rights must be prescribed for by law. Second, the objective of the restriction must pursue one of the legitimate aims enshrined in the article, and lastly, the restriction must be necessary in a democratic society. ${ }^{68}$ Similar to how the ECJ dealt with the Dynamic Medienand and the Sayn-Wittgenstein cases, ${ }^{69}$ the ECtHR too has traditionally left a wide margin of appreciation for States with regard to which national restrictions on fundamental rights are allowed, particularly in socioeconomic matters, ${ }^{70}$ therefore favouring local values to a great extent in the interplay between universalism and particularism of human rights. ${ }^{71}$ However, as we have seen, in certain cases where a national measure would put an excessive burden on individuals, this margin of appreciation may be limited. ${ }^{72}$

64. ECtHR, Bah v. the United Kingdom, Judgment of 27 September, Application No. 56328/07, para. 47.

65. ECtHR, Yordanova and Others, Judgment of 24 April 2012, Application No. 25446/06, para. 118,126 and 130; ECtHR, Winterstein and Others v. France, Judgment of 17 October 2013, Application No. 27013/07.

66. F. Tulkens, 1 Journal européen des droits de l'homme (2013), p. 8 et seq.; ECtHR, Hutten-Czapska v. Poland, Judgment of 19 June 2006, Application No. 35014/97; ECtHR, Almeida Ferreira and Melo Ferreira v. Portugal, Judgment of 21 December 2010, Application No. 41696/07; ECtHR, A.M.B. and Others v. Spain, Judgment of 28 January 2014, Application No. 77842/12.

67. Case C-169/14 Sánchez Morcillo.

68. ECtHR, Chassagnou and Others v. France, Judgment of 29 April 1999, Application No. 25088/94, 28331/95 and 28443/95, para. 113.

69. Case C-244/06 Dynamic Medien, EU:C:2008:85; Case C-208/09 Sayn-Wittgenstein, EU:C:2010:806.

70. ECtHR, Fábián v. Hungary, Judgment of 5 September 2017, Application No 78117/13, para. 115.

71. J. Sweeney, 'A "Margin of Appreciation" in the Internal Market: Lessons from the European Court of Human Rights', 34 Legal Issues of Economic Integration (2007), p. 27.

72. E. Wolfgang, 'Human Rights in the EU: Rethinking the Role of the European Convention on Human Rights After Lisbon', 7 European Constitutional Law Review (2011), p. 64; R. O'Gorman, 'The ECHR, the EU and the Weakness of Social Rights Protection at the European Level', 12 German Law Journal (2011), p. 1834. 


\section{B. Assessment}

Overall, it is true that the ECtHR has increasingly interpreted the provisions in a way that protects claimants' right to a minimum subsistence, particularly when the claimant in question is considered to be 'vulnerable'. This is not to say that this trend constitutes a Convention-based 'social minimum' entitling individuals to a certain degree of welfare protection. Rather, it requires contracting parties to comprehensively assess matters of substantive equality when imposing measures affecting the right to social protection. On this note, the case-law of the ECtHR lightens the burden of restrictive measures on those who are more affected or vulnerable. As such, instead of reviewing whether applicants have the right to a minimum subsistence, what the ECtHR analyses in these cases is the procedural obligation of States to take the adequate steps to ensure that (austerity) measures are, in as much as possible, distributed fairly. ${ }^{73}$

\section{The ECSR}

While the ECSR is not a court of law per se, it has clearly established itself as a quasi-judicial body in the monitoring of compliance with the ESC through two parallel mechanisms: national reporting and the collective complaints procedure. This monitoring has created an extraordinary amount of case-law on the interpretation of the different provisions of the ESC, also as regards living standards. $^{74}$

The ESC does not recognize the right to human dignity as such. However, the ECSR has previously held that poverty is a violation of the right to human dignity ${ }^{75}$ which should be tackled by means of access to resources. ${ }^{76}$ This section focuses on a number of provisions of the ESC that aim at providing access to resources. Because Article 34 CFR, discussed above, draws directly from the ESC, it is logical to start with the provisions that inspired it in the first place, namely, Articles 12 ESC and 13 ESC on social security and social assistance respectively. This section will then look into the right to fair remuneration and conclude with the specific right to protection against poverty and social exclusion and the right to housing (Articles 30 and 31 of the Revised ESC).

\section{A. The right to social security}

As far as the first two indents of Article 34 CFR go, they model after Article 12 ESC on the right to social security. This provision encompasses a fourfold obligation for contracting parties to: (1) establish or maintain a social security system that (2) maintain the level required by the ILO Convention 102, (3) progressively raise the level of the social security system and (4) take steps to ensure equal treatment between nationals of other contracting parties.

The case-law of the ECSR has further interpreted these obligations. Admittedly, Article 12 ESC does not impose a specific system of social security for the contracting parties. Rather, it creates an obligation for them to progressively establish - and maintain - an adequate level of social security.

73. D. Kagiaros, 25 European Public Law (2019), p. 535. The ECtHR requires such measures to be quite disproportionate to find a breach: ECtHR, Seiko v. Lithuania, Judgment of 11 February 2020, Application No 82968/17, para. 34.

74. H. Cullen 'The Collective Complaints System of the European Social Charter: Interpretative Methods of the European Committee of Social Rights', 9 Human Rights Law Review (2009), p. 62.

75. ECSR, FEANTSA v. The Netherlands, Complaint No 86/2012, 17 June 2017, para. 219; ECSR, ATD v. France, Complaint No 33/2006, 5 June 2008, para. 163.

76. ECSR, Statement of Interpretation on Article 30 (2013); ECSR, Conclusions 2005, Slovenia, p. 214. 
How this has been interpreted, particularly in light of the scarcity of case-law before the ECJ, is key to fleshing out the content of Article 34 CFR. Firstly, the ECSR requires all contracting parties to cover every branch of social security that is covered in the ILO Convention $102,{ }^{77}$ which goes beyond that of Article $34 \mathrm{CFR}$, and includes also family benefits, medical care or survivor's benefits. Secondly, social security systems must be collectively financed and must ensure that the benefits lie above the poverty line, which is the minimum threshold to ensure a decent standard of living. ${ }^{78}$ Thirdly, the conditions for entitlement must be reasonable and the loss of income must be addressed in a timely manner. Fourthly, in order to comply with the ESC, social security schemes must cover a majority of the employees with at least basic benefits, health care as well as family benefits. Lastly, state parties must provide for an appeal body before an independent authority and ultimately before the judiciary.

It is clear that the obligations under Article 12 ESC are much broader and detailed than those provided under Article 34(1) CFR, at least when read stricto sensu. In the absence of an interpretation by the ECJ, the case-law of the ECSR could substantiate this matter. Not only would this mean a broadening of the scope of Article 34 CFR by covering also family benefits, medical care or survivor's benefits and aiming for a high coverage, but it would also establish a clear and international threshold to measure adequacy of benefits. The last obligation, in turn, is essential to provide remedy for social security, as Article 34(1) CFR has a limited justiciability. In this vein, Member States must have appellative and review procedures, in line with the requirements under Article 47 CFR, that offer the possibility to challenge adverse decisions. ${ }^{79}$

Quite remarkable is how specific the ECSR is framing the level of adequacy, which is defined as a replacement income of at least $40 \%$ of the previous income, as long as this percentage reaches a minimum of $50 \%$ of the national median income calculated on the basis of the AROP threshold. If this falls below the $50 \%$ threshold, then there is a breach of Article $12 \mathrm{ESC}$, ${ }^{80}$ but where it lies between $40 \%$ and $50 \%$, the ECSR has considered supplementary benefits, such as those provided by social assistance. ${ }^{81}$ Strikingly, while this adequacy is calculated on the basis of the AROP threshold, which puts the poverty line on $60 \%$ of the median equivalized income, the ECSR 'only' finds a violation when the social security benefit is 'manifestly' inadequate, which is equivalent to or below $40 \%$ of the median equivalized income (or $50 \%$ when no other benefit can be accounted for). ${ }^{82}$ This could be understood as a level of severity in inadequacy that must be found in order to find a violation. As such, one could interpret that $40 \%$ median equivalized income as the 'essence' that is necessary for a life in dignity.

While Article 12(3) ESC may suggest otherwise, the ECSR has accepted certain limitations to the right to social security ${ }^{83}$ When limiting Article 12 ESC, the ECSR has made a clear distinction

77. ECSR, Conclusions XIII-4, Statement of Interpretation on Article 12 (1967), at 36.

78. ECSR, Conclusions 2006, Bulgaria, at 118; ECSR, Conclusions 2006, Estonia, at 107.

79. R. White, in S. Peers et al. (eds), The EU Charter of Fundamental Rights: A Commentary, p. 24.

80. ECSR, IKA-ETAM v. Greece, Collective Complaint No. 76/2012, 22 April 2013, para. 74; ECSR, Conclusions 2009, Ireland; ECSR, Conclusions 2009, France; ECSR, Conclusions 2009, Finland.

81. ECSR, Finnish Society of Social Rights v. Finland, Complaint No 88/2012, 9 September 2014, para. 63; ECSR, Conclusions 2013, Hungary.

82. ECSR, Finnish Society, para. 64.

83. The ECSR has held that 'in view of the close relationship between the economic and social rights, the pursuit of economic goals is not necessarily incompatible with the progressive obligation [of Article 12(3)].' ECSR, Conclusions XIV-1 (2002), p. 46. 
between restricting measures for the purpose of dismantling the social security system and arrangements aiming at preserving such systems. ${ }^{84}$ In this vein, the ECSR has held that if a measure aims at preserving a social security system, it may be justified as a legitimate aim to restrict Article 12 ESC as long as such a measure is proportionate to achieve this aim. ${ }^{85}$ Much like in the jurisprudence of the ECtHR, when assessing proportionality, the ECSR too has emphasized the need to consider the effect that restrictive measures would have on vulnerable groups. The ESCR profusely refused the possibility of reducing social security systems to mere social assistance systems and obliges contracting parties to maintain at least a basic and compulsory social security system that does not undermine the protection against socioeconomic risks. ${ }^{86}$

\section{B. The right to social assistance}

Article 13 ESC enshrines the right to social and medical assistance according to which any person who lacks adequate resources, including social security entitlements, should be granted adequate assistance and care when needed and should not result in diminishing a person's political and social rights. In addition, this provision conveys an obligation to provide appropriate services like advice and personal help to prevent, remove or alleviate family want. Article $13 \mathrm{ESC}$ also requires equal treatment between nationals of other contracting parties that legally reside in the territory in compliance with the European Convention on Social and Medical Assistance. Remarkably, the right to social assistance departs from the moral duty of charity and recognizes an obligation for contracting parties. ${ }^{87}$ As opposed to social security, the main eligibility criteria for social assistance is individual need regardless of affiliation to a social security scheme, payments or professional status. ${ }^{88}$ The ECSR has recognized, however, that contracting parties may have a different consideration as to whether a benefit is seen as social security or assistance.

With some targeted exceptions for particular groups, ${ }^{89}$ the ECSR has consistently held that a social assistance system must be universal and payable to any individual on the ground that a person is in need alone. ${ }^{90}$ However, when a person is fit to work, this entitlement might be subject to the willingness of the claimant to be employed or receive vocational training. On a similar note, the ECSR also allows for a minimum period of residence requirement to be imposed by States before equal treatment applies. This is with the exception of emergency assistance, that should be provided to all regardless of their legality in the country and should cover basic needs. ${ }^{91}$

84. ECSR, Conclusions XIII-4, at 139; ECSR, Conclusions XIV-1, at 48; ECSR, Sindicato dos Magistrados do Ministerio Publico v. Portugal, Complaint No 43/2007, 3 December 2008, para. 42.

85. ECSR, Conclusions 2009, p. 615; ECSR, Conclusions 2013, p. 29; ECSR, Austria, Conclusions XV-1 (1998) p. 44; ECSR, Luxemburg, Conclusions XV-1, p. 63.

86. ECSR, Armenia, Conclusions 2013, at 12; ECSR, Georgia, Conclusions 2013, at 14; ECSR, Moldova, Conclusions 2013, at 28; ECSR, Georgia, Conclusions 2013, p. 14.

87. ECSR, Conclusions I, Statement of Interpretation on Article $13 \S 1$ (1969), p. 65.

88. ECSR, Finnish Society, para. 110. ECSR, Conclusions XIII-4, Statement of Interpretation on Articles 12 and 13 (1996), at 34 .

89. ECSR, Conclusions 2009, France; ECSR, Conclusions X-2, Spain (1990), p. 121; ECSR, Conclusions XIII-4, Statement of Interpretation on Article 13 (1996), p. 54.

90. ECSR, ERRC v. Bulgaria, Complaint No 48/2008, 18 February 2009, para. 38.

91. ECSR, FIDH v. France, Complaint No 14/2003, 8 September 2004; ECSR, Defence for Children International v. The Netherlands, Complaint No 47/2008, 20 October 2009; ECSR, FEANTSA; ECSR, CEC v. The Netherlands, Complaint No. 90/2013, 1 July 2014. 
As far as the level of these benefits go, Article 13 ESC requires contracting parties to provide adequate assistance ensuring a decent life covering, at least, the basic needs. ${ }^{92}$ These basic needs are understood to be covered when the level of assistance is not manifestly below the AROP threshold. ${ }^{93}$ Just as with social security benefits, social assistance too is considered to be "manifestly' below the poverty line when a benefit does not reach $50 \%$ of the median equivalized income that is calculated on the basis of the AROP threshold. Article 13 ESC does not require that social assistance is granted in a specific form, as long as it ensures a decent standard. Even though the provision does not per se require contracting parties to have an income guarantee system, the ECSR has found that all contracting parties without an income guarantee are non-compliant with Article 13 ESC. ${ }^{94}$

The benefits will be granted as long as the need persists ${ }^{95}$ and they may be limited when there is a legitimate aim as long as this limitation does not deprive the beneficiary from a bare minimum of subsistence. ${ }^{96}$ In relation to the right to access to justice, there is an obligation for the contracting parties to not make this right dependent solely on the administrative authorities but to also provide the right to appeal. ${ }^{97}$

There is no doubt from the above that under the ESC, contracting parties have a clear and concrete obligation to provide a minimum floor of social protection. This minimum should be considered when conducting reforms to the social protection systems. ${ }^{98}$

\section{The right to fair remuneration}

The right to fair wages is specifically enshrined under Article 4 ESC and requires wages to be sufficient for a decent standard of living. On this note, the ECSR has interpreted that the idea of decent standards goes beyond mere rudimentary necessities such as food, clothing and housing and should also cover a necessary participation in cultural, educational and social activities. ${ }^{99}$ Concretely, in order to be considered 'decent', wages must at least reach $60 \%$ of a national average equivalized wage and to be considered 'fair', the net value of the minimum wage provided by the statutory rule of collective agreement is compared to the net average wage. ${ }^{100}$ For wages that lie between $50 \%$ and $60 \%$, contracting parties can justify that such a wage is sufficient to ensure a decent standard of living, ${ }^{101}$ but any less than $50 \%$ will be considered 'unfair' ${ }^{102}$

92. ECSR, Conclusions XIII-4, Statement of Interpretation on Article $13 \S 1$ (1996), p. 54; ECSR, Conclusions XIV-1, Portugal (1998), p, 701.

93. ECSR, Finnish Society, para. 111; ECSR, Conclusions 2004, Lithuania, p. 373.

94. ECSR, Conclusions XIII-4, Statement of Interpretation on Article $13 \S 1$ (1996), p. 54; ECSR, Conclusions 2006, Moldova, at 122.

95. ECSR, Conclusions XVIII-1, Spain (1998), p. 745.

96. ECSR, Conclusions 2006, Estonia, at 208; ECSR, Conclusions 2009, Estonia; ECSR, Conclusions XIII-4, Statement of Interpretation on Article 13 (1996), p. 52.

97. ECSR, Conclusions I, Statement of Interpretation on Article $13 \S 1$ (1969), p. 64.

98. G. Vonk and M. Olivier, 'The Fundamental Right of Social Assistance (Europe and Africa) and a National Perspective (Germany, the Netherlands and South Africa), 21 European Journal of Social Security (2019), p. 219.

99. ECSR, Statement of interpretation on Article $4 \S 1$ (2010).

100. ECSR, Conclusions XVI-2 - Denmark - Article 4-1 (1997).

101. ECSR, Conclusions 2003 - France - Article 4-1 (2003).

102. CoE, The European Committee of Social Right's Conclusions 2018/ Protection of worker's rights in Europe: Shortcomings found, but also positive development in certain areas (2019). ECSR, GENOP-DEI and ADEDY v. Greece, Complaint No 66/2011, 23 May 2012, para. 60. 


\section{Poverty and housing}

Worded in line with a human rights approach to poverty, ${ }^{103}$ Article 30 of the Revised ESC recognizes a separate right to protection against poverty and social exclusion. According to this, poverty is a deprivation because of lacking resources that arise from (1) State parties' failure to ensure the right to access to healthcare, ${ }^{104}$ or (2) failure to provide a minimum income to persons in need (3) or to adopt a co-ordinated approach that promotes access to housing for people at risk of poverty. ${ }^{105}$ It follows that Article 30 ESC requires contracting parties to develop a coordinated approach to promote effective access to employment, housing, training, education, culture and medical assistance for those who are at risk of poverty and social exclusion and their families. The right to adequate housing is specifically enshrined in Article 31 and encompasses a right to adequate and affordable housing and the responsibility of contracting parties to adopt measures for a gradual elimination of homelessness.

Rather than imposing a right to an individual claim, Article 30 ESC imposes an obligation on contracting parties to deploy resources to access social rights as long as poverty and social exclusion persist. ${ }^{106}$ Here too, the ECSR has relied on the AROP threshold. In this case, compliance with Article 30 ESC is measured in relative poverty terms, which is $60 \%$ of the AROP threshold. ${ }^{107}$

Remarkably, the ECSR has linked this provision to Articles 1 and 34 CFR, stressing that Member States are bound, because of these provisions, to take all necessary steps to its implementation during economic crises, when in fact beneficiaries need protection the most. ${ }^{108}$

\section{E. Assessment}

The ESC, a far more insightful and protective instrument on social rights, seems to create several 'degrees' of protection regarding social security, social assistance, the right against poverty and social exclusion and the right to a fair remuneration. The different protective layers are conveniently associated to the AROP threshold. In this vein, it appears that the ESC considers an income below 40\% AROP to be 'manifestly' below what is acceptable and to be insufficient to ensure a life in dignity, which a contrario reads that at least that $40 \%$ is necessary to cover basic needs such as food, accommodation and healthcare. Covering these needs is an imperative to live a life in dignity which, in turn, seems to align with the case-law of the ECJ regarding 'core' benefits that are necessary to have a 'dignified' standard of living. A second layer, which is sufficient to have a 'decent' standard of living, lies in the $50 \%$ median equivalized income, which suffices not only to cover basic needs but also to participate in cultural, educational and societal activities that are equally necessary. In the case of wages, any less than $50 \%$ of the median equivalized income is considered 'unfair'. In order to live a life out of the risk of poverty and social exclusion, however, the ECSR requires an income above $60 \%$, which suggests that at least that much is necessary to have an 'adequate' standard of living.

103. ECSR, DCI v. The Netherlands, Complaint No 47/2009, 20 October 2009, para. 81; ECSR, COHRE v. Italy, Complaint No 58/2009, 25 June 2010, para. 117.

104. ECSR, DCI v. Belgium., Complaint No 69/2011, 23 October 2012, para. 100.

105. ECSR, ATD, para. 169.

106. ECSR, Statement of Interpretation on Article 30 (2013); ECSR, Conclusions 2003, France, p. 214

107. ECSR, Conclusions 2005, Norway, p. 580; ECSR, Conclusions 2005, Slovenia, p. 674.

108. ECSR, General Introduction to Conclusions XIX-2 (2009). 
Even though the ESC provides the most extensive and protective catalogue on social rights, both the reporting and complaint mechanisms are highly dependent on contracting parties' commitment, given the reliance on the provided information and the lack of direct enforceability of the conclusions and decisions of the ECSR. As far as the justiciability of the rights in the ESC under EU law is concerned, since the ESC is not EU law - as much as these provisions build on the ESC and all Member States are signatory to the ESC - it remains largely ignored by the ECJ, which not only limits synergies between different human rights systems, but also allows the ECJ to restrict social rights beyond what the ECSR has considered appropriate. This brings me to the next section.

\section{Building bridges}

The different provisions and case-law of the three (quasi)judicial bodies examined in this contribution provide a very different protective content regarding living standards. It is argued here that there are a number of lessons to draw from the $\mathrm{CoE}$ bodies and that the ECJ should strive for better synergies through an improved judicial dialogue. Beyond the obvious rationale of providing a more protective social dimension, there are a number of reasons to justify and even require such synergies.

\section{A. Better synergies}

For one, there is a normative requirement in a number of provisions in the EU that make a link between EU law and the CoE instruments and to a certain extent, require some degree of compliance. This is particularly true regarding the EU and the ECHR, obvious from Article 6 TEU that refers to the accession to the ECHR and recognizes the content of the ECHR as constituting general principles of EU law. This is echoed by Article 52(3) CFR that protects the content of the ECHR by establishing a presumption of legal synergy and Article 53 CFR that explicitly includes the ECHR in its non-regression clause. ${ }^{109}$ The latter provision also includes a general reference to international instruments, which should guarantee social standards as seen, inter alia, under the ESC. Unlike for the ECHR, Article 6 TEU does not refer to the ESC or provide any guidance in clarifying what the relationship between EU law and the ESC is, but this connection can still be traced in a number of other provisions, both explicitly and implicitly. The TEU refers to 'the attachment to fundamental social rights as defined by the ESC', and TFEU too imposes a (soft)requirement to 'have in mind' the ESC, among others, when developing its social dimension (Article 151 TFEU). ${ }^{110}$ At a time where the Union seems more willing than ever to explore its social competences, this relationship might prove important when drafting the content of future initiatives. The ECJ has acknowledged this relationship as well, ${ }^{111}$ by referring to the ESC and the commitment of Member States as signatory parties to it. Because all Member States are a party to

109. J. Krommendijk, 'The Use of ECtHR Case-law by the Court of Justice after Lisbon: The View of Luxemburg Insiders', 22 Maastricht Journal of European and Comparative Law (2015), p. 812.

110. 'The Union and the Member States, having in mind fundamental social rights such as those (emphasis added) set out in the European Social Charter [.]'

111. Case C-684/16 Max-Planck-Gesellschaft zur Förderung der Wissenschaften, EU:C:2018:874, para. 70; Case C-350/ 06 Schultz-Hoff and Others, EU:C:2009:18, para. 37; Case C-579/12 RX-II Réexamen Commission v. Strack, EU:C:2013:570, para. 27 
the ESC, the non-regression clause in Article 153(4) TFEU could also be understood as instructing any initiative adopted under these premises to not compromise the level of protection granted by the ESC. At a stretch, an argument could be made suggesting that because the ESC is embedded in the constitutional traditions of the Member States, its protection level should be considered a general principle (Article 6 TEU). A coherent and harmonious relationship between different sources of fundamental social rights, in turn, seems essential for untapping (and respecting) the horizontal social clause under Article 9 TFEU. ${ }^{112}$

In addition to the normative requirements, there are other compelling reasons to promote better synergies between these bodies. First, the $\mathrm{CoE}$ - for our case particularly the ESC - is a more experienced and ripened instrument that could enrich the currently vague social provisions under EU law. This is further reinforced by the fact that many of the provisions in the CFR are modelled after the ESC, which should encourage the ECJ to interpret them in the light of the referring instruments. ${ }^{113}$ This would not be without precedent. In fact, the ECJ has recognized the ESC as expressing a principle of EU social law, which should not be interpreted restrictively. ${ }^{114}$

The last, and perhaps the most persuasive, argument refers to the potential disruption of the international law order and a consequent lowering of the social protection granted by international instruments. Even though there is a general presumption that the EU is compatible with international instruments, this has proven controversial over the years and peaked with the Viking and Laval case-law ${ }^{115}$ and the imposition of austerity measures. ${ }^{116}$ This is most notably the case of the five collective complaints (No. 76-80/2012), against Greece's pension reform in the context of the 2007 economic crisis. The ECSR found that even though these reforms did not by themselves breach Article 12 ESC, their cumulative effect entailed a significant degradation of the standard of living of pensioners. Subsequently, it held that the Greek government did not conduct the necessary research to assess the full effect of the reform package, particularly on vulnerable groups such as pensioners. ${ }^{117}$ Remarkably, the ECSR considered that social protection floors, as provided by the ESC, national constitutions and other international instruments, cannot be eliminated by a contracting party regardless of whether the State at issue is 'forced' to take such measures in order to comply with a Memorandum of Understanding (MoU). ${ }^{118}$ These cases, as well as others at the

112. A. Aranguiz, "Social Mainstreaming Through the European Pillar of Social Rights: Shielding "The Social" from "The Economic" in the EU Policymaking', 20 European Journal of Social Security (2018), p. 341.

113. A. Światkowski and M, Wujczyk, in F. Pennings and M. Seeleib-Kaiser (eds.), EU Citizenship and Social Rights, p. 20.

114. Case C-268/06 Impact, EU:C:2008:223, para. 112; C-116/06 Kiiski, EU:C:2007:536.

115. ECSR, LO and TCO v. Sweden, Complaint No. 85/2012, 3 July 2013. CoE, 'State of Democracy, Human Right and the Rule of Law in Europe (2014), p. 41; ILO, '2010 Report of the Committee of Experts on the Application of Conventions and Recommendations' (2010), p. 209; ILO, 'Observation (CEACR) - adopted 2012, published 102nd ILC session' (2013).

116. ECSR, GSEE v. Greece, Complaint No 111/2014, 23 March 2017; ECSR, LO and TCO. M. Rocca, 'A Clash of Kings. The European Committee of Social Rights on the "Lex Laval" ... and on the EU Framework for the Posting of Workers', 3 European Journal of Social Law (2013), p. 217.

117. ECSR, IKA-ETAM; ECSR, POPS v. Greece, Collective Complaint No 77/2012, 7 December 2012; ECSR, I.S.A.P. v. Greece, Collective Complaint No 78/2012, 7 December 2012; ECSR, POS-DEI v. Greece, Collective Complaint No 79/2012, 7 December 2012; ECSR, ATE v. Greece, Collective Complaint No 80/2012, 7 December 2012. M. Salomon, 'Of Austerity, Human Rights and International Institutions', LSE Working Paper (2015); E. De Becker, 17 German Law Journal (2016), p. 277.

118. ECSR, IKA-ETAM, para. 78 
national level, ${ }^{119}$ show that not only does EU law have a rather limited protective core but, what is more worrisome, that Member States might enter into conflict when the implementing legislation is challenged.

Interpretative divergences can be extremely problematic in cases of overlapping membership, which is the case for most Member States. In this regard, two considerations should be noted. First, because of the principle of primacy in EU law, Member States will be inclined to follow EU law. Secondly, the ECJ has explicitly held that when a national law is in conflict with an international instrument (in this case the ECHR), EU law does not require Member States to disapply the national rule. ${ }^{120}$ Hence, in cases of utter conflict, Member States are forced to choose between the $\mathrm{EU}$ or the $\mathrm{CoE}$ and are more likely to choose the former, which not only leads to a lower threshold of social protection but also generates a fundamental problem of the international rule of law. ${ }^{121}$ Moreover, because the EU is not a member to these instruments, EU interventions cannot directly be reviewed by their bodies, regardless of the considerable (negative) impact that economic governance has in domestic social protection systems.

The Viking-Laval quartet downgraded the fundamental status of social rights while simultaneously narrowing the justifications of free movement restriction on social grounds. Because of these cases, it became easier to decline possible limitations to free movement on the basis of their impact on social standards. ${ }^{122}$ In the absence of a substantiated protection at the EU level (in the CFR), the lack of compliance with international instruments and the possible limitation on national standards in favour of economic interest paints a rather obscure picture regarding the protection of fundamental social rights.

In light of the above, there should be little doubt about the need - not only desirability - for better legal synergies between EU law and the CoE. Some have argued in favour of acceding to the ESC to complete the parallel accession to the ECHR (if ever materialized), ${ }^{123}$ others claim that it is unfeasible in both political and legal terms ${ }^{124}$ and that, moreover, it would create problems for the autonomy of EU law. ${ }^{125}$ Instead, better synergies can be achieved by means effective judicial dialogue. The legislator too, both at the EU and national level, plays a key role in this regard. By incorporating references to the different instruments, it can ensure that the judiciary interprets existing legislation in light of the relevant case-law, which, to some extent, would tackle the "nonjusticiability' of social rights. ${ }^{126}$

119. E. Psychogiopoulou, 'Welfare Rights in Crisis in Greece: The Role of Fundamental Rights Challenges', 1 European Journal of Social Law (2014), p. 12; E. de Becker, 'The Constraints of Fundamental Social Rights on EU Economic Monitoring', 17 European Journal of Social Security (2014), p. 123.

120. Case C-571/10 Kamberaj, para. 63.

121. M. Rocca, "Enemy at the (Flood) Gates: EU "Exceptionalism" in Recent Tensions with the International Protection of Social Rights', 7 European Labour Law Journal (2016), p. 52; S. Garben, 'The problematic interaction between EU and international law in the area of social rights', 7 Cambridge International Law Journal (2018) 77.

122. A. Bücker and W. Warneck, 'Viking - Laval - Rüffert: Consequences and policy perspectives' ETUI Report 111 (2010).

123. O. De Schutter, 'The Accession of the European Union to the European Social Charter: A Fresh Start', European Journal of Human Rights (2019), p. 155.

124. S. Garben, 'The Constitutional (Im)balance between "the Market" and "the Social" in the European Union', 13 European Constitutional Law Review (2017), p. 55.

125. Ibid., p. 97.

126. A. Úbeda de Torres, 'Justiciability and Social Rights', in C. Binder et al. (eds), Research Handbook on International Law and Social Rights, (Elgar, 2020), p. 43. 


\section{B. Drawing positive lessons from the council of Europe}

Once the need for better synergies has been established, the only thing left to discuss is the content of these synergies, which could materialize both in initiatives of the legislator, but also through a more active judicial dialogue in the case-law of the ECJ. With regard to ensuring a certain living standard through the right to dignity and social protection, there are a number of lessons to be drawn from the case-law discussed above. These can conveniently be grouped in two scenarios.

Scenario one refers to substantiating the relatively empty vessels of Articles 1, 31 and 34 CFR as well as specific legal provisions that might be read in their light. For example, this could be the case of the (for now proposal) directive on minimum wages, which ought to be interpreted in accordance with Article 31 CFR. ${ }^{127}$ As a more matured and socially-centred instrument, the ESC has more to offer to the substantive content of EU provisions. In relation to living standards, what is arguably most interesting from the work of the ECSR is that in recent years it has defined these subsistence minimums (whether in the form of social security, social assistance or fair remuneration) in a very concrete manner, namely by referring to the AROP threshold developed by Eurostat itself. This precision in measuring the adequacy of social protection systems, through a familiar indicator to the EU, allows for a nuanced evaluation of the performance of States with regard to their obligation to provide a level of living standards. This quantifiable minimum may prove useful in future interpretations of EU social legislation when evaluating what an acceptable benefit or wage is and find breaches where Member States are 'manifestly' below it. Another 'lesson' in substantive matters concerns the material scope of the Article 34 CFR, which should cover other social security rights such as family benefits, medical care and survivor's benefits. The ESC also requires social assistance to be provided as long as it is necessary and in a universal manner (conditional upon residency, though not on emergency assistance) and sufficient to cover not only rudimentary needs, but also social participation.

Unless specific legislation is drawn with these purposes, however, such a proactive role by the ECJ is unlikely, and would raise issues of separation of powers and subsidiarity. In view of increasing initiatives in this domain, however, the Court might be prone to interpret such initiatives so as to align with the case-law of the ECSR.

The second scenario refers to future potential limitations of these rights and brings us back to the initial discussion on human dignity as the inviolable right that represents the impenetrable 'essence' of other provisions in the CFR. Amidst the great crisis that Covid-19 signifies, this is perhaps a more urgent scenario to consider. Under this scenario, the CFR could provide a more protection-centred approach to secure the standards that are already in place. This would prevent Member States and EU institutions from adopting measures that would significantly deteriorate or abolish existing systems or schemes ${ }^{128}$ and thus entail a considerable departure from the current approach. In this vein, the procedural safeguards that the ECtHR has put forward in its case-law

127. Note, however, that interpreting this level of adequacy in a way that interferes with pay as defined by the ECJ may raise concerns regarding the principle of conferral in view of Article 153(5) TFEU. See for a detailed analysis: A. Aranguiz and S. Garben, 'Combating Income Inequality in the EU: A Legal Assessment of a Potential EU Minimum Wage Directive', 46 European Law Review (2021), p. 156.

128. S. Peers and S. Prechal, in S. Peers et al. (eds), The EU Charter of Fundamental Rights: A Commentary, p. 1455. 
could (and should) feed into future limitations on welfare systems, particularly, when such limitations are imposed, directly or indirectly, by the EU.

Compared to the ESC, the protective content vis-à-vis social rights is considerably lower in the ECHR but unlike the ESC, EU law is bound to its level of protection (Article 53 CFR). Accordingly, the case-law of the ECtHR obliges Member States to conduct a thorough proportionality test for the benefit of the poor and vulnerable before imposing limitations on their rights. In this sense, the ECtHR has included in its proportionality assessment the following considerations: personal circumstances (vulnerability) but also the burden placed on individuals (explicitly associated to Article 34 CFR), the need for a balanced distribution of these measures and the obligation for administrations to inform the applicant about the available options before drastic measures are taken. At the very least, EU law should take on board these considerations within its proportionality test under Article 52 CFR and explicitly consider the personal implications, particularly with regard to vulnerable groups, and their prospect of improvement. Without this, it can hardly be argued that the essence of these rights, and as such the right to human dignity, is properly being guarded by the ECJ. A step further would be to utilize international indicators when exercising the proportionality test. It is important to reiterate that there is are precedents where ECJ used the AROP threshold in the context of limiting old-age pensions. ${ }^{129}$ It could, in a similar vein, not allow future limitations when this means putting (vulnerable) people under the same unacceptable threshold. Either way, any limitation, however justified and necessary, should not result in the dismantling of a social protection system.

This second scenario will become crucial in the years to follow the Covid-19 pandemic in ensuring that limits to minimum subsistence-related rights do not merely require an objective justification, just as 'fiscal consolidation' sufficed in Sotiropoulou, but also that the measures imposed to attain such an objective do not pose an excessive and discriminatory burden upon vulnerable individuals.

\section{Conclusion}

Traditionally conceived as an economic union, the EU often falls short in its fundamental rights protection, particularly regarding its social dimension. Other (quasi)judicial bodies have had a longer time to ripen without the pressing burden of having to live up to an economic goal. For a couple of years now, however, the EU seems invested in delivering a more social union by the hand of the EPSR. This instrument is the living proof that the social acquis of the EU is nothing but a collection of social rights from national and international instruments recognized by the Member States. As such, developing the EPSR symbolizes a fantastic learning opportunity for the EU to incorporate some of the protective safeguards and substantive interpretations developed under the umbrella of the more matured case-law of the ECtHR and ECSR. This article has made the case for incorporating elements of the ECtHR and the ECSR in the future interpretations by the ECJ for a coherent and enhanced protection of a standard of living that is compatible with a life in dignity. After analysing the different bodies of case-law and providing compelling reasons to improve the legal synergies between the different bodies, the article suggests a number of 'learning points' both in procedural and substantive matters. 


\section{Acknowledgement}

I would like to thank the anonymous reviewers for their useful remarks and the members of my doctoral jury for pushing me to seek answers to the questions in this article. Special thanks go to Mathieu Leloup for reading several draft versions of this article. Any mistakes remain my own.

\section{ORCID iD}

Ane Aranguiz (D) https://orcid.org/0000-0002-2413-9504 